\title{
Pembangunan Berkelanjutan: Analisis terhadap UULLAJ
}

\author{
Zairin Harahap
}

\begin{abstract}
If sustainable development does not constitute a green camouflage; the'slogan must be implemented in every govemment policy. One of these is in the field of regulation. This paper tries to study the traffic regulations (Undang-Undang Lalu Lintas dan Angkutan Jalan) whether it has been in line with the essence of the sustainable development concept or it is just the green camouflage.
\end{abstract}

\section{Pendahuluan}

Istilah pembangunan berkelanjutan merupakan terjemahan dari sustainable development yang dipopulerkan oleh World Commission on Environment and Development (WCED) yang dibentuk oleh PBB lewat publikasi bukunya yang berjudul Our Common Future. Tugas utama Komisi itu mengadakan penelaahan penyerasian lingkungan (environ- ment) dan pembangunan (development) yang dalam kenyataannya sering dipertentangkan satu dengan yang lain. ${ }^{1}$

Kerusakan lingkungan hidup yang terjadi di mana-mana menurut Korten sebagai akibat dari kesalahan konsep ekonomi yang dipakai:
Korten mengutip Kenneth Boulding yang membedakan dua macam ekonomi: ekonomi koboi dan ekonomi kapal ruang angkasa. Ekonomi koboi, sumber daya alam tersedia secara tidak terbatas. Si koboi dapat melakukan apa saja ketika dia berada di padang rumput yang terbentang luas dihadapannya. Kalau seseorang hidup dalam sebuah kapal ruang angkasa, keadaannya akan sangat berlainan. Segalanya serba terbatas. Kalau seseorang itu tidak hati-hati menggunakan sumber daya alam yang ada, bukan saja membahayakan diri seseorang tersebut, tapi juga orang-orang lain yang ada di kapal.

'Koesnadi Hardjasoemantri. "Aspek Hukum Pembangunan Berkelanjutan." Makalah yang disampaikan pada Pembukaan Kuliah Program Pascasarjana U GM. Tahun Akademik 1996/1997. Tanggal 2 September 1996. HIm. 4. 
Bumi pada saat ini, menurut Korten sudah berubah dari sebuah padang yang luas tempat para koboi mengembara, menjadi sebuah kapal ruang angkasa. Karena itu, sistem ekonomi koboi tidak dapat dipertahankan. Sistem ekonomi kapal ruang änkasa harus dikembangkan. Kalau tidak, semuanya, tanpa terkecuali, akan hancur dan binasa. Oleh karenanya, perbaikan yang dilakukan bukan sekedar perbaikan tambal sulam. Tetapi harus diubah secara mendasar sistem perekonomian sekarang yang ada. Masalah yang paling menentukan bagi pembangunan pada dasawarsa 90 -an bukanlah pertumbuhan. Masalahnya adalah transformasi. Transformasi pembangunan ini harus dapat menyelesaikan 3 (tiga) persoalan dasar: masalah keadilan, masalah kesinambungan sumber daya alam, dan masalah partisipasi. ${ }^{2}$ Dalam ekonomi kapal ruang angkasa, dipandang segala sesuatu sebagai salah satu bagian dari alam (a part of nature) bukan sebagai sesuatu yang terpisah dari alam (apart from nature) sebagaimana yang dianut oleh sistem ekonomi koboi.

Pentingnya pembangunan berkelanjutan ini, karena pelaksanaan pembangunan tidak dapat dilepaskan dari penggunaan sumber daya alam (resource). Sementara sumber daya alam itu terbagi atas: sumber daya alam yang dapat diperbaharui (renewble resource), seperti; kayu, tumbuh-tumbuhan; dan sumber daya alam yang tidak dapat diperbaharui (non renewble resource) seperti; batubara, minyak, dan bahan tambang lainnya. Permasalahan pokoknya menurut Emil Salim adalah bagaimana merigolah sumber daya alam dengan bijaksana agar tertumpang proses pembangunan yang berkesinambungan bagi peningkatan kualitas hidup rakyat dari generasi demi generasi sepanjang masa. ${ }^{3}$

\section{Pembangunan Berkelanjutan}

W.CED merumuskan pembangunan berkelanjutan sebagai pembangunan yang memenuhi kebutuhan masa kini tanpa mengurangi kemampuan generasi mendatang untuk memenuhi kebutuhan mereka sendiri. Selanjutnya disebutkan bahwa di dalam definisi itu mengandung 2 (dua) gagasan penting, yakni: 1) gagasan kebutuhan, khususnya kebutuhan esensial kaum miskin sedunia yang harus diberi prioritas utama, dan; 2) gagasan keterbatasan, yang bersumber pada kondisi teknologi dan organisasi sosial terhadap kemampuan lingkungan untuk memenuhi kebutuhan kini dan hari depan. ${ }^{4}$

Definisi tersebut menurut JP Pronk, mengandung 3 (tiga) komponen; pertumbuhan produksi (pembangunan ekonomi), distribusi yang adil (perjuangan melawan kemiskinan), dan pemeliharaan ecoscope (ekologi yang dapat dipertahankan). ${ }^{5}$ Menurut Koesnadi Hardjasoemantri, definisi tersebut dengan

2Arief Budiman. 1993. "Kata Pengantar"' buku David C Korten. Menuju Abad 21 Tindakan Sukarela dan Agenda Global. Jakarta: Yayasan Obor Indonesia.

'Emil Salim. 1986. Pembangunan Berwawasan Lingkungan. Jakarta: LP3ES. Hlm. 169-170.

4WCED. 1987. Our Common Future. Oxford University Press. HIm. 43.

5.J. Pronk. 1993. Sedunia Perbedaan. Jakarta: Yayasan Obor Indonesia. HIm. 109. 
tajam menempatkan tanggung jawab generasi sekarang terhadap generasi-generasi mendatang, yang berarti hubungan antar generasi dengan muatan tanggung jawab. Generasi sekarang mempunyai tanggung jawab untuk melestarikan fungsi lingkungan, sehingga generasi mendatang mendapat lingkungan hidup yang baik dan sehat yang merupakan hak penuh mereka. ${ }^{6}$

Pembangunan yang tidak mempertimbangankan kemampuan lingkungan telah mendatangkan sejumlah persoalan lingkungan, salah satunya adalah masalah pemanasan global. Pemanasan global secara umum disebabkan oleh dua hal: pembakaran bahan fosil dalam industri, mobil, pembangkit listrik, dan sebagainya; dan emisi berbagai gas dari kegiatan industri termasuk juga penggunaan dan pembuatan CFC. CFC inilah yang merusak lapisan ozon sehingga memungkinkan sinar ultraviolet yang membahayakan menembus bumi. ${ }^{7}$

Penggunaan kendaraan bermotor dapat menjadi ancaman bagi keberlangsungan lingkungan dan kesehatan umat manusia. . Jed Greer dan Kenny Bruno ${ }^{8}$ mengatakan bahwa kendaraan bermotor merupakan sumber pencemar nomor satu di dunia. Untuk membantu memulas hijau segala akibat dari produksi dan pemakaian mobilnya, General Motors Corporation (GM) meluncurkan sebuah program untuk menanam sebuah pohon per. kawasan bagi setiap mobil yang terjual. Namun, sumbangan program ini menurut Jed Greer dan Kenny Bruno, positifnya hanya minimal. Seandainya benar-benar mengakui dampak produk mereka pada lingkungan dan melibatkan diri lebih dari sekedar kamuflase, mungkin bisa diharapkan adanya penekanan lebih pada efisiensi bahan bakar, pada bahan bakar yang dapat diperbaharui, dan bahkan pada angkutan umum dan sepeda. Rusdian Lubis dan Widodo Sambodo, mengatakan bahwa lebih dari $50 \%$ pencemaran udara di muka bumi ini disebabkan oleh gas buangan kendaraan bermotor. ${ }^{9}$ Selain pencemaran udara oleh industri, pencemaran udara di Indonesia banyak diakibatkan oleh transportasi. ${ }^{10}$ Sebagai akibat dari tingginya pencemaran udara, di Yokaichi, Jepang, terjadinya penyakit asma massal." Di Indonesia, hal ini memang belum terjadi. Tetapi, harus disadari bahwa petugas Polantas, pengamen, pengemis, sering sekali berada di perempatan jalan. Sekarang mereka mungkin belum merasakan akibatnya.

Di Daerah Istimewa Yogyakarta (DIY) tentang angkutan umum yang menimbulkan

${ }^{6}$ Koesnadi Hardjasoemantri. Op.Cit. Him. 1-2.

7Hira Jhamtani. 1993. "Kata Pengantar." Buku Gerald Foley. Pemanasan Global: Siapa yang merasa panas? Jakarta: Yayasan Obor Indonesia.

${ }^{8} \mathrm{Jed}$ Greer dan Kenny Bruno. 1999. Kamuflase Hijau: Membedah Ideologi Lingkungan Perusahaanperusahaan Transnasional. Jakarta: Yayasan Obor Indonesia. HIm. 177-179.

"Rusdian Lubis dan Widodo Sambodo. 1994. "Masalah Pencemaran Lingkungan di Indonesia." Dalam Profil Indonesia. Jakarta: CIDES. HIm. 227.

${ }^{10}$ Achmad Setiyadi. "Selamatkan Udara Kota Kita." Dalam Pikiran Rakyat. Bandung. Tanggal 31 Mei 2000. Hlm. 8.

"ibid. 
polusi telah sering dikeluhkan oleh masyarakat. ${ }^{12}$ Di samping itu, walaupun belum tentu memiliki korelasi terhadap tingkat polusi yang ditimbulkan, namun perlu kiranya dikaji tentang adanya sinyalemen yang mengatakan bahwa sekitar $54,10 \%$ angkutan umum yang beroperasi di DIY usianya telah cukup tua, ${ }^{13}$ dan jumlah angkutan umum yang beroperasi sudah melebihi kapasitas kebutuhan maupun jalur yang ada. ${ }^{14}$

\section{UULLAJ dan Pencemaran}

Tingkat pencemaran yang ditimbulkan emisi kendaraan bermotor makin mencemaskan. Beberapa pengendara sepeda motor khususnya, harus menutup bagian wajahnya agar terlindung dari asap kendaraan bermotor lainnya, khususnya bis kota. Beberapa pengendara sepeda motor juga sepertinya dengan sengaja menyete! kendaraannya sedemikian rupa agar dapat menghasilkan suara yang keras.

Mereka, sepertinya tidak pernah merasa berdosa bahwa perbuatan tersebut telah merugikan orang lain dan secara otomatis mengancam keberlangsungan lingkungan hidup yang baik dan sehat itu sendiri. Oleh karenanya, tidaklah berlebihan apabila HennJuri Uibopuu, mengatakan bahwa pelestarian alam telah berfokus pada fauna, flora, dan halhal penting yang lain dari lingkungan hidup manusia, dan sudah ada keberhasilan dalam melindungi itu semua dari kerusakan. Tetapi, dewasa ini dapat ditegaskan, manusia sendiri telah menjadi spesies yang membahayakan. ${ }^{15}$

Mungkin banyak yang bertanya-tanya, mengapa polisi membiarkan begitu saja kendaraan bermotor mengeluarkan asap begitu tebal dan suara yang begitu keras. Padahal, hak dari semua pengguna jasa jalan adalah sama, sementara perbuatan tersebut jelas-jelas sangat mengganggu konsentrasi, kenyamanan, bahkan keselamatan pengguna jasa jalan lainnya. Pada saat yang bersamaan, polisi sangat rajin melakukan pemeriksaan atau razia terhadap surat-surat kendaraan bermotor yang secara subtansial tidaklah memiliki korelasi dengan kelancaran lalu lintas, khususnya keselamatan bagi pengguna jasa jalan pada umumnya.

\section{Hak atas Lingkungan}

Dalam Pasal 5 ayat (1) UUPLH disebutkan bahwa setiap orang mempunyai hak yang sama atas lingkungan hidup yang baik dan sehat. Hak ini disebut juga sebagai subjective rights yang merupakan bentuk paling luas untuk perlindungan seseorang. Berdasarkan hak ini, maka seseorang dapat mempunyai suatu tuntutan yang sah untuk meminta kepentingannya atas lingkungan hidup yang baik dan sehat dihormati. Tuntutan tersebut

${ }^{12}$ Kedaulatan Rakyat. Tanggal 21 Agustus 2000. HIm. 2.

${ }^{13}$ Kedaulatan Rakyat. Tanggal 25 September 2000 . HIm. 2.

${ }^{14}$ Kedaulatan Rakyat. Tanggal 19 September 2000. HIm. 2.

${ }^{15} \mathrm{Henn}-J u r i$ Uibopuu. 1993. Hak Individu atas Lingkungan Hidup yang Bersih, dalam T Mulya Lubis (Penyunting), Hak-hak Asasi Manusia dalam Masyarakat Dunia: Isu dan Tindakan. Jakarta: Yayasan Obor Indonesia. HIm. 157-158. 
mempunyai 2 (dua) fungsi yang berbeda, yakni; the function of defense dan the function of performance. Fungsi, yang pertama, dikaitkan dengan hak membela diri terhadap gangguan dari luar yang menimbulkan kerugian pada lingkungannya. Fungsi yang kedua, dikaitkan dengan hak menuntut dilakukannya sesuatu tindakan agar lingkungannya dapat dilestarikan, dipulihkan, atau diperbaiki. ${ }^{16}$

Untuk melakukan tuntutan atas kasus di atas, tidaklah mudah, di samping membutuhkan biaya yang sangat besar. Dalam kaitannya dengan tuntutan ganti kenugian, misalnya; Pasal 34 ayat (1) UUPLH mengatakan Setiap perbuatan melanggar hukum berupa pencemaran dan atau perusakan lingkungan hidup yang menimbulkan kerugian pada orang lain atau lingkungan hidup, mewajibkan penanggung jawab usaha dan atau kegiatan untuk membayar ganti rugi dan atau melakukan tindakan tertentu. Dari ketentuan tersebut dapat diketahui bahwa Pasal 34 ayat (1) UUPLH menganut asas liability based on fault, sehingga membawa konsekuensi bahwa penggugat harus dapat membuktikan adanya hubungan kausalitas antara asap atau kebisingan kendaraan bermotor tersebut dan kerugian yang dideritanya. Dengan dẹmikian, meskipun UUPLH mengakui bahwa lingkungan hidup yang baik dan sehat merupakan subjective rights, namun, penghormatan terhadap hak-hak ini berkaitan dengan kasus di atas, sangat sulit untuk dapat dituntut pemenuhannya.

Sebenarnya, Undang-undang Nomor 14 Tahun 1992 tentang Lalu Lintas dan Angkutan
Jaian (UULLAJ) sudah cukup akomodatif dalam mengantisipasi kasus di atas. Dalam Pasal 50 ayat (1) disebutkan bahwa Untuk mencegah pencemaran udara dan kebisingan suara kendaraan bermotor yang dapat mengganggu kelestarian lingkungan hidup, setiap kendaraan bermotor wajib memenuhi persyaratan ambang batas emisi gas buang dan tingkat kebisingan. Selanjutnya dalam ayat (2) disebutkan bahwa Setiap pemilik, pengusaha angkutan umum dan atau pengemudi kendaraan bermotor, wajib mencegah terjadinya pencemaran udara dan kebisingan sebagaimana dimaksud dalam ayat (1), yang diakibatkan pengoperasian kendaraannya. Untuk memaksakan agar ketentuan Pasal 50 tersebut dipatuhi, maka dalam Pasal 67 secara tegas disebutkan bahwa Barangsiapa mengemudikan kendaraan bermotor yang tidak memenuhi persyaratan ambang batas emisi gas buang atau tingkat kebisingan sebagaimana dimaksud dalam Pasal 50 ayat (1) dan ayat (2) dipidana dengan pidana kurungan paling lama 2 (dua) bulan atau denda setinggi-tingginya Rp 2.000.000,- (dua juta rupiah).

Berdasarkan ketentuan Pasal 67 tersebut, maka aparat penegak hukum seharusnya setiap saat juga meläkukan pemeriksaan atau razia terhadap persyaratan teknis dan laik jalan kendaraan bermotor, tidak hanya melakukan pemeriksaan atau razia terhadap kelengkapan surat-suratnya. Namun, dalam kenyataannya, pemeriksaan atau razia terhadap persyaratan teknis dan laik jalan tersebut hampir tidak pernah dilakukan. Bahkan, ketika melakukan

\footnotetext{
${ }^{-}{ }^{16}$ Koesnadi Hardjasoemantri. 1996. Hukum Tata Lingkungan. Edisi keenam. Cetakan keduabelas. Yogyakarta: Gadjah Mada University Press. HIm. 119-120.
} 
perpanjangan terhadap berbagai surat kendaraan bermotor yang diperlukan, boleh dikatakan lebih bersifat formalitas belaka.

Ketentuan sanksi yang dapat dijatuhkan tersebut, dapat dijelaskan dengan teori etika tentang hukuman legal, yakni; teori retributivisme dan teori utilitarisme. ${ }^{17}$ Menurut teori retributivisme, hukuman diberikan karena si pelaku harus menerima hukuman itu demi kesalahannya. Hukuman menjadi retribusi yang adil bagi kerugian yang sudah diakibatkan. Teori ini memandang ke belakang, yaitu pada subjek tindakan kejahatan, sehingga lebih merupakan pemberian nestapa atau balas dendam kepada si pelaku. Oleh karenanya, teori ini menganut prinsip punitur quia peccatum est (dihukum karena bersalah). Teori utilitarisme memusatkan perhatian pada konsekuensikonsekuensi pada masa depan dari suatu hukuman. Hukuman, sebagai suatu tindakan terhadap seorang penjahat, dapat dibenarkan secara moral bukan terutama karena si terhukum telah terbukti bersalah melawan hukum, melainkan karena hukuman itu mengandung konsekuensi-konsekuensi positif bagi si terhukum, korban, dan juga orang-orang lain dalam masyarakat. Efek-efek yang terpenting dari penerapan teori ini adalah bersifat preventif, yaitu kontribusinya terhadap pencegahan kesalahan-kesalahan atau terhadap penurunan jumlah pelanggaranpelanggaran hukum. Oleh karenanya, prinsip dasar dari teori ini adalah punitur ut ne peccetur (dihukum agar tidak bersalah lagi).
Berangkat dari teori-teori tersebut, dapat dikatakan bahwa sanksi yang dimuat dalam ketentuan Pasal 67 tersebut, lebih dekat kepada menganut teori retributivisme. Karena, sanksi yang dijatuhkan bukan ditujukan untuk mengakhiri sumber permasalahan, tetapi lebih pada memberikan nestapa kepada si pelaku. Apabila dianut teori utilitarisme, maka sanksinya harus ditujukan untuk mengakhisi sumber permasalahan, yakni; kendaraan bermotor tersebut ditahan. Kendaraan tersebut baru dapat dioperasikan kembali, apabila sudah memenuhi persyaratan teknis dan laik jalan sesuai dengan ketentuan yang berlaku. Menghukum si pelaku dengan seberatberatnya tidaklah memiliki korelasi dengan pengakhiran sumber permasalahan, karena kendaraan tersebut masih bebas beroperasi, sehingga otomatis masih mengeluarkan asap dan atau suara yang melebihi nilai ambang batas yang ditetapkan. Oleh karenanya, sanksi yang dimuat dalam ketentuan Pasal 67 tersebut, seharusnya menganut teori utilitarisme.

Di samping itu, ketentuan tentang nilai ambang batas, sesungguhnya merupakan persoalan administratif. Oleh karenanya, melanggar nilai ambang batas identik dengan melanggar ketentuan administratif. Konsekuensinya, maka sanksi yang dijatuhkan kepada si pelanggar seharusnya adalah bersifat administratif bukan bersifat perdata maupun pidana sebagaimana yang terdapat dalam ketentuan Pasal 67 UULLAJ tersebut. Contoh sanksi administratifnya adalah kendaraan tersebut ditahan, pembekuan

${ }^{17 Y o n g ~ O h o i t i m u r . ~ 1997 . ~ T e o r i ~ E t i k a ~ t e n t a n g ~ H u k u m a n ~ L e g a l . ~ J a k a r t a: ~ P T ~ G r a m e d i a ~ P u s t a k a ~ U t a m a . ~}$ 
sementara atau pencabutan izin trayek. Dengan penjatuhan sanksi adminitratif seperti itu, dapat ditujukan langsung untuk mengakhiri sumber perbuatan yang dilarang bukan sekedar menghukum si pelaku. Penambahan sanksi lainnya seperti; sanksi perdata maupun pidana sebagai penerapan sanksi yang bersifat kumulasi eksternal harus memperhatikan asas keseimbangan, sehingga tidak akan sampai menjatuhkan sanksi yang tidak sepadan dengan pelanggaran yang dilakukan seseorang.

\section{Penegakan Hukum}

Berdasarkan ketentuan Pasal 2 Peraturan Pemerintah Nomor 42 Tahun 1993 tentang Pemeriksaan Kendaraan Bermotor di Jalan disebutkan bahwa pemeriksaan kendaraan bermotor di jalan dilakukan oleh polisi dan pegawai negeri sipil (PNS) yang memiliki kualifikasi tertentu di bidang lalu lintas dan angkutan jalan. Wewenang polisi dalam melakukan pemeriksaan kendaraan bermotor di jalan berdasarkan ketentuan Pasal 3 , hanya meliputi persyaratan administratif pengemudi dan kendaraan. Dalam praktek, yang sering diperiksa oleh polisi yang berkaitan dengan persyaratan admininistarif pengemudi adalah SIM (Surat Izin Mengemudi), sedangkan yang berkaitan dengan persyaratan administarif kendaraan, mencakup; STNK (Surat Tanda Nomor Kenderaan), helm, kaca spion, plat nomor, lampu-lampu, dan lain-lain. Sedangkan wewenang PNS berdasarkan ketentuan Pasal 4, meliputi persyaratan teknis dan laik jalan. Selanjutnya, dalam Pasal 8 disebutkan bahwa PNS dalam melaksanakan pemeriksaan kendaraan bermotor di jalan, berwenang untuk melakukan pemeriksaan terhadap tanda bukti lulus uji dan pemeriksaan terhadap fisik kendaraan. Tujuan pengujian itu sendiri, paling tidak menurut ketentuan Pasal 132 Peraturan Pemerintah Nomor 44 Tahun 1993 tentang Kendaraan dan Pengemudi, dilaksanakan dalam rangka menjamin keselamatan, kelestarian lingkungan, dan pelayanan umum.

Dari ketentuan pasal-pasal tersebut di atas, sangat jelas bahwa pemeriksaan atau razia terhadap kendaraan bermotor di jalan tidak hanya menyangkut persyaratan administratif pengemudi dan kendaraan sebagaimana yang sering dilakukan oleh polisi. Tetapi, juga terhadap persyaratan teknis dan laik jalannya suatu kendaraan bermotor' di jalan. Pemeriksaan atau razia terhadap yang terakhir ini bukan merupakan wewenang polisi, tetapi menupakan wewenang dari PNS. Persoalannya sekarang adalah bahwa ketentuan pasal-pasal tersebut telah menjadi black letter law (huruf mati). Karena, hampir tidak pernah, atau bahkan sama sekali tidak pernah, kita menyaksikan PNS yang dimaksud melakukan pemeriksaan atau razia terhadap persyaratan teknis dan laik jalan suatu kendaraan bermotor di jalan.

Di dalam praktik yang terjadi di DIY adalah sebaliknya, yakni; dalam pengujian kendaraan ditemukan berbagai penyimpangan, antara lain dengan membayar uang yang melebihi dari tarif yang ditentukan banyak kendaraan yang dinyatakan lulus uji sebelum dilakukan pengujian, yakni; dari tarif resmi sebesar Rp 6.500 - (enam ribu lima ratus ribu rupiah) petugas menaikkannya hingga mencapai sebesar Rp 45.000,- (empat puluh lima ribu rupiah)..$^{18}$ Sementara itu, terhadap kendaraan

\footnotetext{
${ }^{18}$ Kedaulatan Rakyat. Tanggal 1 Agustus 2000. HIm. 2.
} 
yang dinyatakan lulus uji, karena lemahnya pengawasan di lapangan, maka setelah keluar dari ruang uji, disinyalir suku cadangnya diganti. Sehingga, kendaraan yang berlalu lalang di jalan tetap mengeluarkan emisi berlebihan yang menimbulkan polusi. ${ }^{19}$

Penerapan ketentuan Pasal 50 jo Pasal 67 UULLAJ jauh lebih mudah daripada penerapan Pasal 34 UUPLH. Penerapan ketentuan Pasal 50 jo Pasal 67 UULLAJ tidak perlu membuktikan apakah telah terjadi perusakan dan atau pencemaran lingkungan akibat emisi gas buang atau kebisingan yang ditimbulkan oleh kendaraan bermotor tersebut. Tetapi, PNS sebagai aparat yang diberi kewenangan dapat langsung melakukan pemeriksaan atau razia di tempat untuk membuktikan apakah kendaraankendaraan bermotor yang diduga atau dicurigai tersebut telah melanggar ketentuan nilai ambang batas emisi gas buang atau tingkat kebisingan yang ditetapkan. Kendaraan yang dicurigai tersebut, kalau tidak memungkinkan diadakan pengujian langsung di tempat. Maka, dapat ditahan untuk kemudian di bawa ke suatu tempat yang telah dipersiapkan untuk dilakukan pengujian, apakah emisi gas buang atau tingkat kebisingannya telah melampaui nilai ambang batas yang ditetapkan. Jika tidak, maka kendaraan tersebut harus dilepas. Tetapi, jika terbukti, maka ketentuan Pasal 67 UULLAJ yang memuat sanksi terhadap pelanggaran tersebut harus diterapkan secara konsekuen.

Dewasa ini untuk wilayah DIY, ketentuan tentang nilai ambang batas telah dituangkan dalam Keputusan Gubernur Kepala Daerah Istimewa Yogyakarta Nomor: 214/KPTS/1991 tentang Baku Mutu Lingkungan Daerah untuk Wilayah Propinsi Daerah Istimewa Yogyakarta. Dalam Keputusan tersebut secara tegas diatur tentang Baku Tingkat Kebisingan dan Baku Mutu Emisi Gas dan Partikel Buang. Baku Mutu Tingkat Kebisingan diatur dalam Lampiran IV yang menyebutkan sebagai berikut:

${ }^{19}$ Kedaulatan Rakyat. Tanggal 21 Agustus 2000. Hlm. 2. 


\begin{tabular}{|c|c|c|}
\hline Nomor & Kategori Peruntukan & Tingkat Kebisisingan \\
\hline 1. & $\begin{array}{l}\text { Fasilitas umum } A_{\text {, }} \text { adalah fasilitas umum yang } \\
\text { meliputi rumah sakit, tempat perawatan kesehatan, } \\
\text { sekolah, tempat ibadah; dan yang sejenis. }\end{array}$ & Leg $\leq 55 \mathrm{~dB}$ \\
\hline 2. & $\begin{array}{l}\text { Fasilitas umum } B \text {, adalah fasilitas umum yang } \\
\text { meliputi pemukiman, perumahan, dan yang } \\
\text { sejenis. }\end{array}$ & Leg $\leq 60 \mathrm{~dB}$ \\
\hline 3. & $\begin{array}{l}\text { Fasilitas umum } C \text {, adalah fasilitas umum yang } \\
\text { meliputi perkantoran, pertokoan, perdagangan, } \\
\text { pergudangan, dan pasar. }\end{array}$ & $\operatorname{Leg} \leq 65 \mathrm{~dB}$ \\
\hline 4. & $\begin{array}{l}\text { Fasilitas umum D, adalah fasilitas umum yang } \\
\text { meliputi industri, terminal angkutan umum, stasiun } \\
\text { kereta api dan yang sejenis termasuk bandar } \\
\text { udara, depo/pool dan pelabuhan laut. }\end{array}$ & $\operatorname{Leg} \leq 70 \mathrm{~dB}$ \\
\hline
\end{tabular}

Ketentuan tersebut; nampaknya tidak menjangkau kebisingan yang ditimbulkan oleh kendaraan bermotor yang sedang beroperasi di jalan raya sebagaimana yang dimaksud Pasal 50 dan Pasal 67 UULLAJ. Dengan demikian, pemeriksaan terhadap tingkat kebisingan kendaraan bermotor di jalan belum memiliki dasar hukum. Keadaan ini, kemungkinan besar disebabkan oleh Keputusan Gubernur tersebut lebih dahulu ada, yakni dikeluarkan tahun 1991, sedangkan UULLAJ dikeluarkan tahun 1992.

Untuk itu, perlu dilakukan revisi terhadap Keputusan Gubernur tersebut. Di samping, untuk menyesuaikan materi muatannya dengan UULLAJ, juga usia dari Keputusan Gubernur tersebut sudah sekitar 9 (sembilan) tahun. Sudah barang tentu dalam kurun waktu tersebut telah terjadi perubahan yang cukup berarti bagi kondisi lingkungan DIY. Kalau berbicara jangka waktu yang ideal tentang masa berlaku suatu peraturan perundangundangan adalah relatif. Masa berlaku 9 (sembilan) tahun untuk ukuran peraturan perundang-undangan di Indonesia boleh dikatakan relatif singkat. Tetapi, karena hal ini sangat terkait dengan masalah lingkungan, maka ukuran yang tepat yang digunakan untuk melakukan revisi adalah kondisi objektif dari lingkungan saat ini.

\section{Simpulan}

Dari kajian tersebut di atas, terlepas dari berbagai kekurangan yuridis yang terdapat dalam UULLAJ. Namun, setidak-tidaknya, UULLAJ tersebut, sesungguhnya telah cukup antisipatif terhadap permasalahan perusakan 
dan atau pencemaran lingkungan sebagai dampak negatif dari pengoperasian kendaraan bermotor. Bahkan, UULLAJ, secara khusus telah mempersiapkan aparat penegakan hukumnya yang berasal dari PNS.

UULLAJ ini sudah berlaku sekitar 8 (delapan) tahun, namun efektivitas PNS yang dipersiapkan sebagai pengawal lingkungan masa depan tidak kunjung datang, apakah kita memang telah selalu membiasakan diri untuk menunggu serba terlanjur baru kemudian sadar. Penegakan hukum tidaklah berhenti pada pembuatan peraturan perundangundangan. Tetapi, jauh lebih penting adalah penerapannya, sehingga Undang-undang tersebut bukan merupakan kamuflase hijau.

Perlu melakukan revisi terhadap materi muatan Keputusan Gubemur Kepala Daerah Istimewa Yogyakarta Nomor. 214/KPTS/1991 tentang Baku Mutu Lingkungan untuk Wilayah Propinsi DIY, dalam rangka penyesuaian terhadap UULLAJ dan kondisi objektif lingkungan DIY saatini. $\square$

\section{Daftar Pustaka}

CIDES. 1994. Profil Indonesia. Jakarta.

Foley, Gerald. 1993. Pemanasan Global Siapakah yang Merasa Panas?. Jakarta: Yayasan Obor Indonesia.

Greer, Jed dan Kenny Bruno. 1999. Kamuflase Hijau Membedah Ideologi Lingkungan Perusahaanperusahaan Transnasional. Jakarta: Yayasan Obor Indonesia.
Hardjasoemantri, Koesnadi. 1996. "Aspek Hukum Pembangunan Berkelanjutan." Makalah yang disampaikan pada Pembukaan Kuliah Program Pascasarjana UGM Tahun Akademik 1996/1997. Yogyakarta.

1996. Hukum Tata Lingkungan. Edisi keenam. Cetakan keduabelas. Yogyakarta: Gadjah Mada University Press.

Korten, David C. 1993. Menuju Abad 21 Tindakan Sukarela dan Agenda Global, Jakarta: Yayasan Obor Indonesia.

Lubis, T Mulya (Penyunting). 1993. Hak-hak Asasi Manusia dalam Masyarakat Dunia Isu dan Tindakan. Jakarta: Yayasan Obor Indonesia.

Ohoitimur, Yong. 1997. Teori Etika tentang Hukum Legal. Jakarta: PT. Gramedia Pustaka Utama.

Pronk, JP. 1993. Sedunia Perbedaan. Jakarta: Yayasan Obor Indonesia.

Salim, Emil. 1986. Pembangunan Berwawasan Lingkungan. Jakarta: LP3ES.

WCED. 1987. Our Common Future. Oxford University Press.

Pikiran Rakyat. Tanggal 31 Mei 2000. Bandung.

Kedaulatan Rakyat. Tanggal 1 Agustus 2000. Tanggal 19, 21, dan 25 September 2000. Yogyakarta. 